\title{
UNIT COST ANALYSIS OF ROUTINE BLOOD EXAMINATION WITH ACTIVITY BASED COSTING METHOD AT H. PADJONGA DG NGALLE HOSPITAL, TAKALAR, SOUTH SULAWESI
}

\author{
Adi Sembodo, Firman Pribadi
}

Master Program of Hospital Management, Universitas Muhammadiyah Yogyakarta

\begin{abstract}
Background: In response to demand for accurate clinical diagnosis, the use of routine blood examination has increased. Activity based costing (ABC) method is widely used as a cost estimate instrument to approximate the true cost of operation. This study aimed to investigate unit cost analysis of routine blood examination with ABC method at H. Padjonga Dg Ngalle Hospital, Takalar, South Sulawesi.

Subjects and Method: This was a case study conducted at H. Padjonga Dg Ngalle Regional General Hospital, Takalar, South Sulawesi. The study was conducted from May to June 2019. The theme of this study was unit cost analysis of routine blood examination with $\mathrm{ABC}$ method. The data were collected by in-depth interview and direct observation. The data were described accordingly.

Results: The unit cost of routine blood tests based on the calculation using ABC method amounted to Rp. 115,615. The unit cost of routine blood tests calculated using the $\mathrm{ABC}$ method was noticeably greater than the real cost applied in RSUD H. Padjonga Dg Ngalle Takalar, with a difference of Rp. 65,615.

Conclusion: Based on the unit cost analysis of the $\mathrm{ABC}$ method, the rate of routine blood tests in Takalar Hospital is still undercosting.

Keywords: routine blood test, unit cost, $\mathrm{ABC}$ method

\section{Correspondent:}

Adi Sembodo. Master Program of Hospital Management, Universitas Muhammadiyah Yogyakarta, Jl. Brawijaya, Geblagan, Bantul, Yogyakarta 55183. Email: sembodo.adi@gmail.com. Mobile: 081327683087.
\end{abstract}

The $6^{\text {th }}$ International Conference on Public Health Best Western Premier Hotel, Solo, Indonesia, October 23-24, 2019 | 296 